Article

\title{
Impact of Foliar Fertilization on Growth, Flowering, and Corms Production of Five Gladiolus Varieties
}

\author{
Endre Kentelky * and Zsolt Szekely-Varga (D)
}

Department of Horticulture, Faculty of Technical and Human Sciences, Sapientia Hungarian University of Transylvania, Sighișoarei 1/C, 540485 Targu Mures, Romania; szekelyvarga.zsolt@gmail.com

* Correspondence: kentelky@ms.sapientia.ro

Citation: Kentelky, E.; Szekely-Varga, Z. Impact of Foliar Fertilization on Growth, Flowering, and Corms Production of Five Gladiolus Varieties. Plants 2021, 10, 1963. https:// doi.org/10.3390/plants10091963

Academic Editors: Jim Moir,

Lukas Hlisnikovsky, Xinhua He and Przemysław Barłóg

Received: 24 August 2021

Accepted: 16 September 2021

Published: 20 September 2021

Publisher's Note: MDPI stays neutral with regard to jurisdictional claims in published maps and institutional affiliations.

Copyright: (c) 2021 by the authors. Licensee MDPI, Basel, Switzerland. This article is an open access article distributed under the terms and conditions of the Creative Commons Attribution (CC BY) license (https:// creativecommons.org/licenses/by/ $4.0 /)$.

\begin{abstract}
Degraded and salt affected soils are appearing more often in cultivated areas. These specific problems could reduce nutrient uptake, which can result in quality and yield loss of the cultivated plants. In order to cope with this pedo-climatic condition growers are applying fertilizers; however, due to inadequate application, soil degradation will continue. Five Gladiolus varieties were subjected to foliar fertilization treatments to assess the effect on the plant's growth parameters, vase durability and daughter corm production. Our results indicate that plants treated with foliar fertilization show significant increase in the measured parameters, flower stem length, vase durability and daughter corm production. In conclusion, our study suggests that application of foliar fertilization can increase Gladiolus plants decoration and propagation, even with a smaller footprint on nature.
\end{abstract}

Keywords: corms; foliar fertilization; Gladiolus; vase durability

\section{Introduction}

Currently in the world $20 \%$ of the cultivated land is degraded and salt affected, which is affecting nutrient uptake and resulting in quality and yield reduction of the cultivated plants. More importantly, these factors are contributing to crop losses worldwide [1,2]. According to several studies, in order to cope with these conditions and increase production, chemical fertilizers are applied, but due to inappropriate application, soil degradation (acidification; salinization; nutrient imbalance; and irregular accumulation of nitrogen, phosphorus and potassium) occurs in the cultivated lands [3,4].

Fertilization can be divided into two main methods: root and foliar fertilization [4]. Foliar fertilization can be absorbed directly through the leaves and can be transported more quickly and efficiently to the other plant organs compared to root fertilization $[5,6]$. Moreover, foliar fertilization can be sprayed at optimum times and concentrations, according to the requirement of different plants, at different growth stages. This type of fertilization can be more suitable to the plant's needs, in contrast to root fertilization $[4,7,8]$.

Gladiolus genus is a perennial, monocotyledonous, geophyte, semi-rustic ornamental plant and includes about 260 species [8,9]. The Gladiolus originates in Mediterranean Europe, Asia, and South and Tropical Africa [10-13]. It can be found as an ornamental garden plant and also as cut flowers used for bouquets and arrangements [13]. These majestic plants are found in different shapes, colours, and sizes, and can be cultivated almost everywhere, but should be considered for regions where spring and summer conditions are favourable [14].

The main aim of the present research was to test the responses to foliar fertilization of five highly cultivated Gladiolus varieties. 'Black Beauty', 'Green Star', 'Nova Lux', 'Zizane', and 'Frizzled Coral Lace' were analysed in the study. The effect of three foliar fertilizersFitofolis, Bionat Plus and Cropmax - and the mixture of the three on the flower quality and the amount of new daughter corms produced by the selected gladioli was investigated. We expected to establish whether any of the five varieties was more suitable for cultivation in the climate conditions of the Carpathian Basin. 


\section{Results}

\subsection{Plant Growth}

Considering the shoot growth, almost all Gladiolus varieties showed small increases in shoot length (Figure 1). However, in the case of 'Green Star' (Figure 1a) the Fitofolis and the $\mathrm{F}+\mathrm{B}+\mathrm{C}$ (the mixture of Fitofolis, Bionat Plus and Cropmax) treatments influenced the shoot growth significantly compared to the control treatments. The effect of the treatment was evident, especially for the 'Black Beauty' gladioli, which showed an increase in growth in all treatments with respect to the controls, with $\sim 10 \mathrm{~cm}$ (Figure 1b).

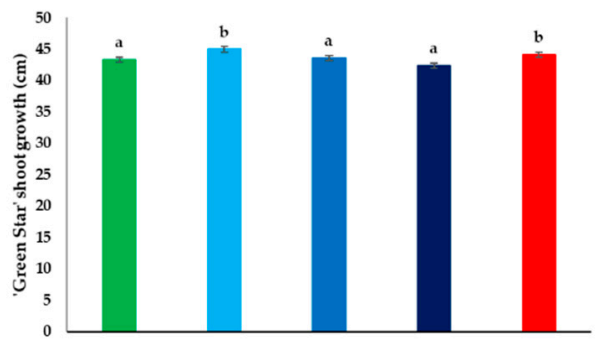

(a)

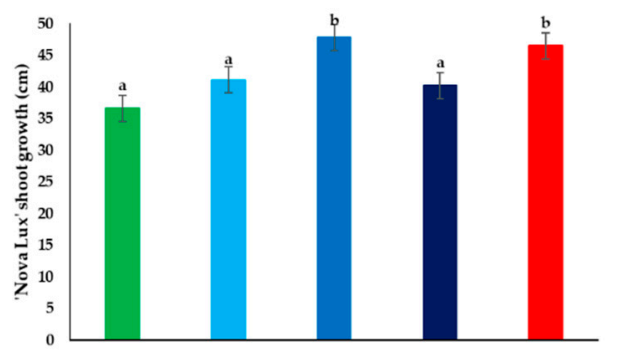

(c)

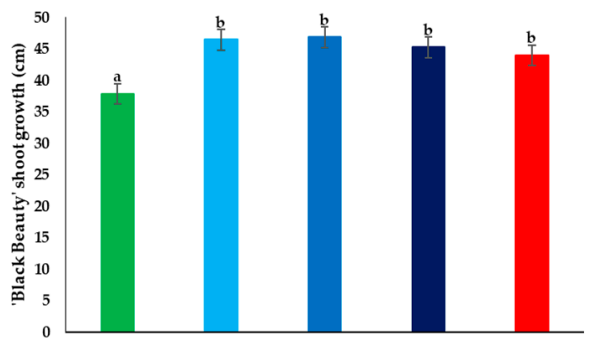

(b)

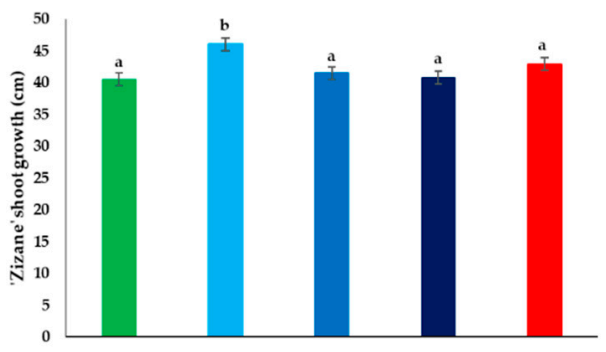

(d)

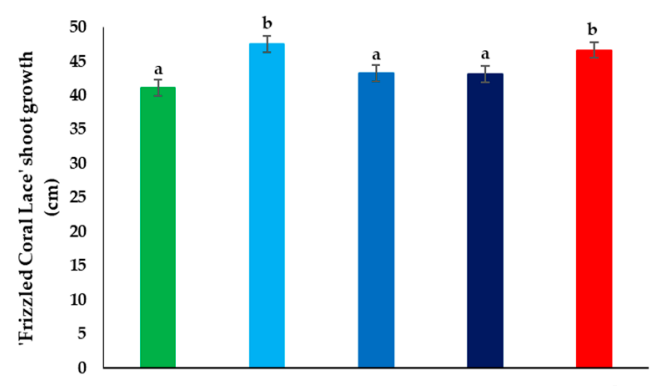

(e)

\section{Control Fitofolis Bionat Plus Cropmax $\square$ F + B + C}

Figure 1. Effect of foliar fertilization on the shoot growth parameters in Gladiolus varieties: 'Green Star' (a), 'Black Beauty' (b), 'Nova Lux' (c), 'Zizane' (d), and 'Frizzled Coral Lace' (e). Plants shoot growth under control conditions, in the presence of the indicated foliar fertilization: Fitofolis, Bionat Plus, Cropmax and the mixture of Fitofolis-Bionat Plus-Cropmax $(F+B+C)$. Shoot growth was measured in all plants just before starting the treatments (13 May), and before the harvesting of the inflorescences (9 August). Bars represent the means \pm SE $(n=10)$. Different letters above the bars indicate significant differences between the treatments, according to Tukey test $(\alpha=0.05)$.

Regarding 'Nova Lux' (Figure 1c), only for the Bionat Plus and F + B + C treatments were significant differences reported; however, all treatments showed small increases (between 5-10 cm) compared to the control plants. An increase in mean shoot growth was 
also reported in 'Zizane' for the Fitofolis treatment (Figure 1d); for 'Frizzled Coral Lace' (Figure 1e), an increase of approximately $4 \mathrm{~cm}$, was observed for the Fitofolis and F + B + C treatments.

Percentage increases in shoot growth of Gladiolus varieties influenced by the foliar fertilization were as follows: for 'Green Star', 'Zizane', and 'Frizzled Coral Lace' the highest percentage increase was recorded with Fitofolis $(3.92 \%, 13.58 \%$, and $15.54 \%)$ compared to the control. In contrast, the smallest percentage increases for the same three varieties were observed with Cropmax $(0.02 \%, 0.61 \%$, and $4.86 \%)$. The 'Black Beauty' reported the highest increase with Bionat Plus (23.81\%) and the smallest percentage increase at F + B + C $(16.27 \%)$. For 'Nova Lux', a 30.6\% increase was found with Bionat Plus compared to only a $9.8 \%$ increase with Cropmax fertilization.

The results of the present study indicated that a variety-specific response exists to foliar fertilization; in most cases the treatments significantly, positively influenced the flower stem growth (Figure 2) compared to the controls.

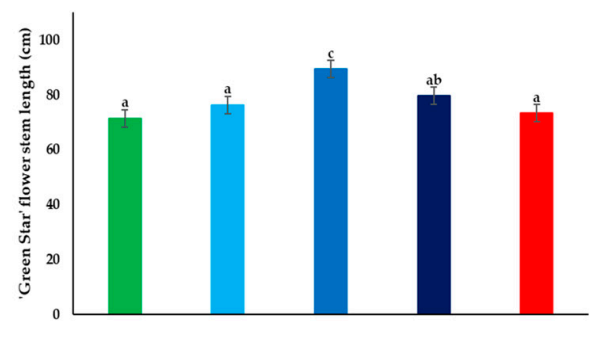

(a)

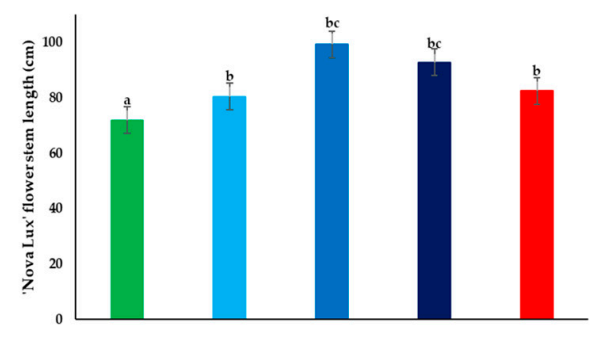

(c)

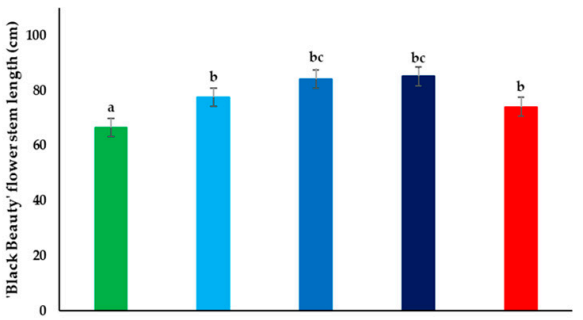

(b)

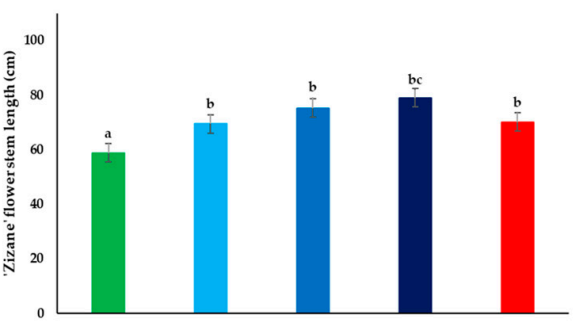

(d)

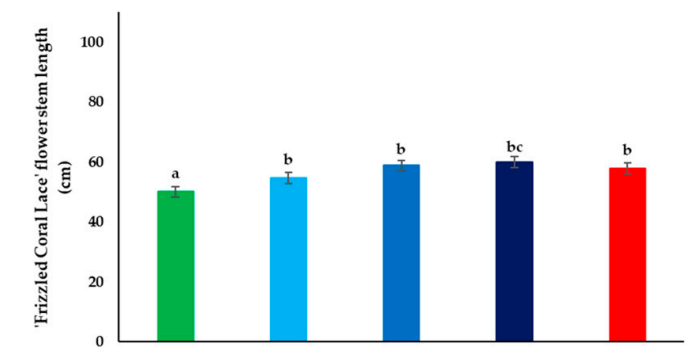

(e)

Control Fitofolis $\square$ Bionat Plus $\square$ Cropmax $\square \mathrm{F}+\mathrm{B}+\mathrm{C}$

Figure 2. Effect of foliar fertilization on flower stem growth parameters in Gladiolus varieties: 'Green Star' (a), 'Black Beauty' (b), 'Nova Lux' (c), 'Zizane' (d), and 'Frizzled Coral Lace' (e). Plant flower stem growth shown under control conditions and in the presence of the indicated foliar fertilization: Fitofolis, Bionat Plus, Cropmax and the mixture of Fitofolis-Bionat Plus-Cropmax $(\mathrm{F}+\mathrm{B}+\mathrm{C})$. Flower stem growth was measured in all plants just before starting the treatments (13 May), and before the harvesting of the inflorescences (9 August). Bars represent the means $\pm \mathrm{SE}(n=10)$. Different letters above the bars indicate significant differences between the treatments, according to Tukey test $(\alpha=0.05)$. 
'Green Star' (Figure 2a) showed significant growth of the flower stem under the Bionat Plus fertilization, with a $19 \mathrm{~cm}$ increase; the other fertilization treatments influenced the flower stem growth, but at smaller percentages.

All types of foliar fertilization increased flower stem length for 'Black Beauty' (Figure 2b), compared to the control plants, in some cases by almost $20 \mathrm{~cm}$. Regarding 'Nova Lux', 'Zizane' and 'Frizzled Coral Lace' Gladiolus (Figure 2c-e), similar results were found for all four fertilization treatments. For these three Gladiolus varieties, growth increase was between 5 and $30 \mathrm{~cm}$ depending on the treatment.

Comparing the stem growth between varieties in all treatments, the highest increase was observed in 'Nova Lux' -almost $30 \mathrm{~cm}$; the least growth was in 'Frizzled Coral Lace'. This could be explained by the variety morphology.

When comparing the flower stem growth to the control, the greatest percentage increases in 'Black Beauty', 'Frizzled Coral Lace', and 'Zizane' were recorded with Cropmax $(27.96 \%, 19.76 \%$, and 34.35\%), in 'Nova Lux' and 'Green Star' with Bionat Plus with $37.91 \%$ and $25.07 \%$, respectively. The lowest percentage increases were observed with Fitofolis ('Nova Lux'-11.82\%, 'Frizzled Coral Lace'-9.18\%, and 'Zizane'-18.02\%) and F + B + C ('Black Beauty'-11.27\% and 'Green Star'-2.66\%) fertilizers.

\subsection{Vase Durability}

Under our experimental conditions, significant differences between the varieties and the treatments were observed in the vase durability of the Gladiolus (Figure 3). When comparing the varieties, it could be concluded that 'Green Star', 'Black Beauty' and 'Nova Lux' had the longest vase durability, whereas 'Zizane' and 'Frizzled Coral Lace' had shorter vase durability, with fewer points.

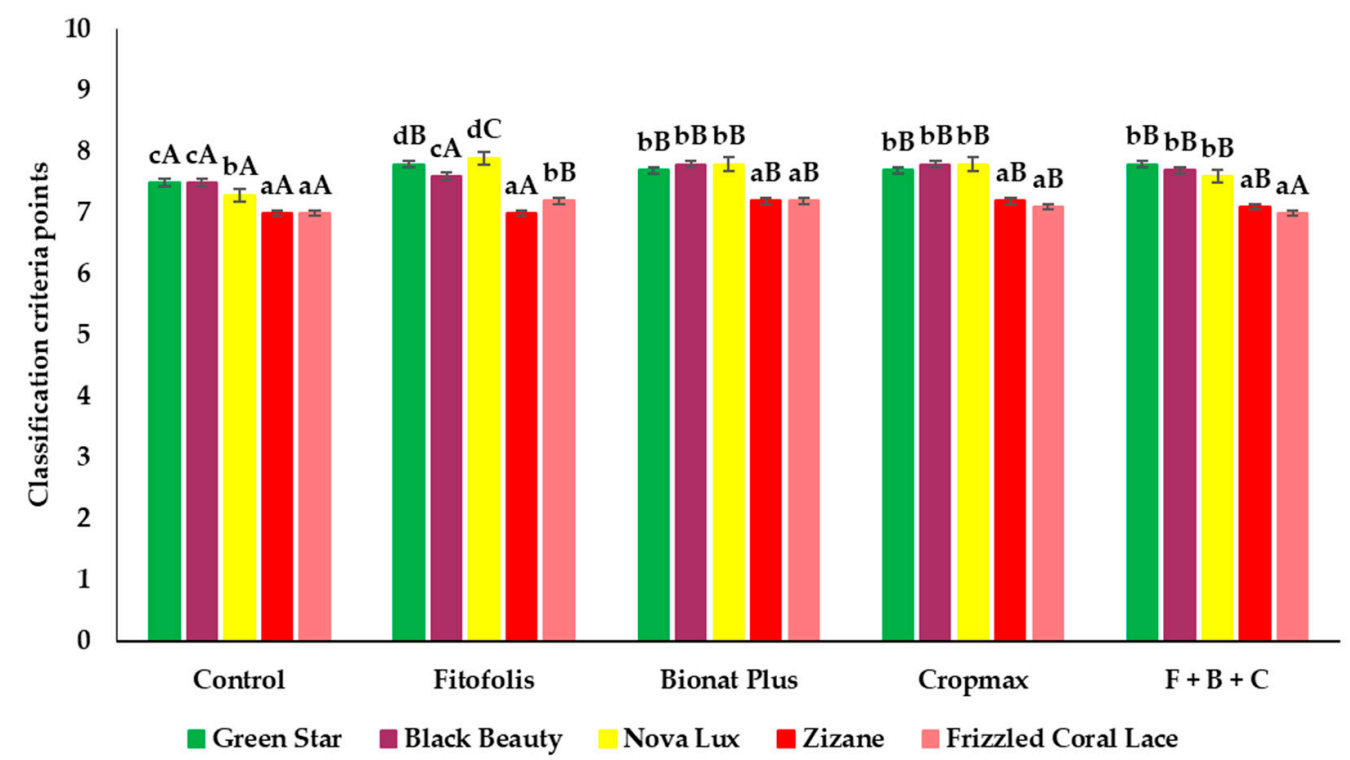

Figure 3. Effect of foliar fertilization on vase durability of Gladiolus varieties: 'Green Star', 'Black Beauty', 'Nova Lux', 'Zizane', and 'Frizzled Coral Lace'. Vase durability of floral stems produced under control conditions and in the presence of the indicated foliar fertilization: Fitofolis, Bionat Plus, Cropmax and the mixture of Fitofolis-Bionat Plus-Cropmax $(F+B+C)$. Bars represent the means \pm $\mathrm{SE}(n=5)$. Different lowercase letters above the bars indicate significant differences between the five varieties for each foliar fertilization, and different uppercase letters indicate significant differences between treatments, according to Tukey test $(\alpha=0.05)$.

Foliar fertilizations influenced vase durability in a positive way, although with small differences. Almost all types of fertilization affected the gladioli durability, supporting the general conclusion of the individual experiments that all varieties responded to fertilization. The average vase durability was 7.45 days. 


\subsection{Daughter Corms Production}

It was concluded that foliar fertilization had a positive effect on the increase in number of daughter corms production.

Under our experimental conditions 'Green Star' and 'Black Beauty' showed significant increases from all types of foliar fertilization, compared to the controls (Figure 4a,b).

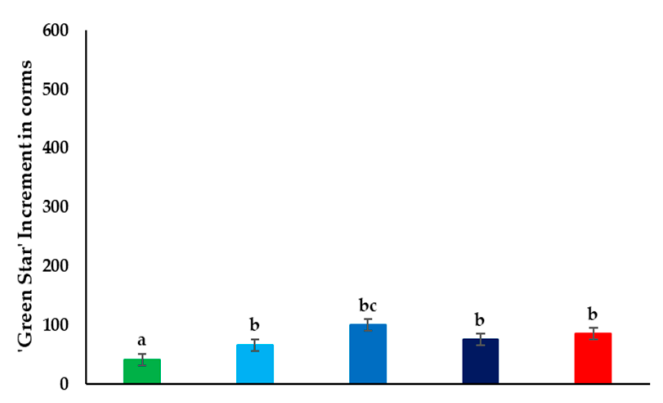

(a)

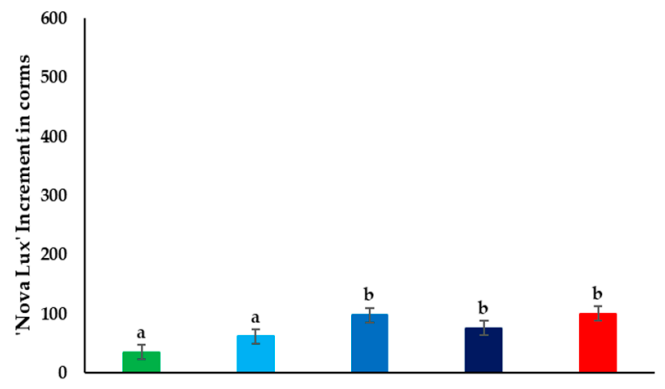

(c)

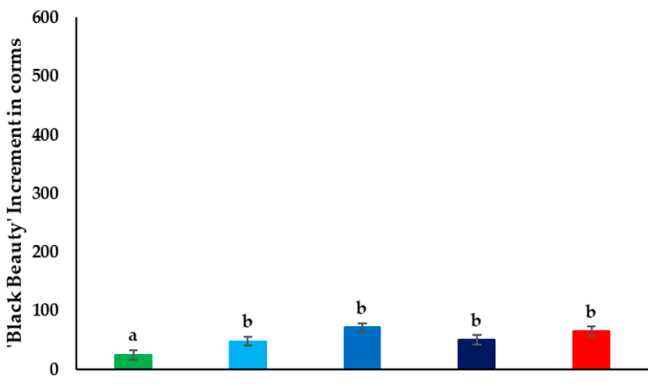

(b)

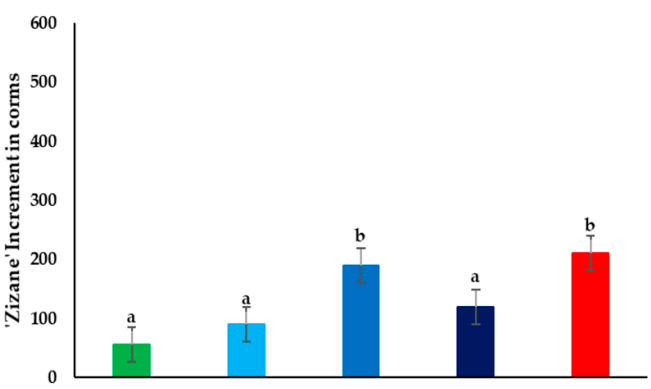

(d)

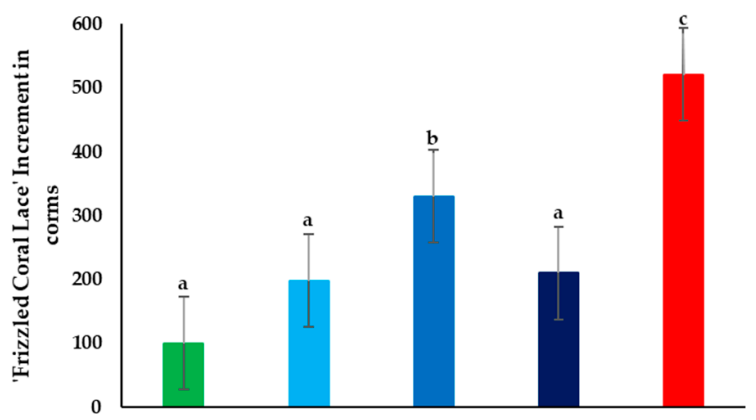

(e)

$\square$ Control Fitofolis $\square$ Bionat Plus $\square$ Cropmax $\square \mathrm{F}+\mathrm{B}+\mathrm{C}$

Figure 4. Effect of foliar fertilization on increment in daughter corms in Gladiolus varieties: 'Green Star' (a), 'Black Beauty' (b), 'Nova Lux' (c), 'Zizane' (d), and 'Frizzled Coral Lace' (e). Increase in daughter corms under control conditions and in the presence of the indicated foliar fertilization: Fitofolis, Bionat Plus, Cropmax and the mixture of Fitofolis-Bionat Plus-Cropmax $(\mathrm{F}+\mathrm{B}+\mathrm{C})$. Bars represent the means $\pm \mathrm{SE}(n=10)$. Different letters above the bars indicate significant differences between the treatments, according to Tukey test $(\alpha=0.05)$.

For 'Nova Lux' (Figure 4c), there was no effect from the Fitofolis treatment. In contrast, the Bionat Plus, Cropmax and $\mathrm{F}+\mathrm{B}+\mathrm{C}$ treatments increased the corms production. Increases in the number of corms were also observed in 'Zizane' (Figure $4 \mathrm{~d}$ ) with the Bionat Plus and $\mathrm{F}+\mathrm{B}+\mathrm{C}$ treatments. 
'Frizzled Coral Lace' (Figure 4e) showed a high increase from the F + B + C treatment, as daughter corms production was five times higher compared to the controls. This result could be influenced also by the variety: comparing the five different Gladiolus varieties, the greatest daughter corm production occurred in this variety.

In the cases of 'Green Star' (60.97\%), 'Black Beauty' (92\%), 'Nova Lux' $(77.14 \%)$, and 'Zizane' $(63.63 \%)$ the smallest percentage increase in relation to the controls were reported from Fitofolis. For 'Frizzled Coral Lace', the Cropmax fertilizer recorded the smallest increase in percentage with a $228.12 \%$ compared to control. The greatest increases were observed with Bionat Plus ('Green Star'-143.9\% and 'Black Beauty'-184\%) and the mixture of the three foliar fertilizers ('Nova Lux'-185.71\%, 'Zizane'-281.81\%, and 'Frizzled Coral Lace' $^{\prime}-714.06 \%$ ).

\section{Discussion}

The results of this experiment show proper foliar fertilization can support and influence the growth, vase durability and daughter corms production of some Gladiolus varieties. Saima et al. [15] found that application of foliar spray affected flower production and it was the best method to getting maximum flower production in Gladiolus. Furthermore, it has a potential effect on the nutrient uptake and on the stimulation of growth parameters and flowering characteristics [5,16]. Foliar fertilization increases micronutrient uptake and physiological and biochemical indexes [17,18]. Many studies suggest that foliar fertilization may help to stimulate the uptake of soil applied fertilizers, which could provide a solution to salt accumulation in the soil [4].

Foliar fertilization was more effective and significantly enhanced the shoot and flower stem growth compared to the control plants. Similar to our study, some researchers reported that foliar fertilization promoted the flower stem growth to the maximum levels in gladioli, which could have a constructive role in the development of the flowers $[15,19,20]$. Similar findings have been described where the administration of foliar fertilization treatments influenced the Calendula inflorescence yield, but not the chlorophyll parameters, where no significant differences were observed between the treatments [21,22].

The data obtained clearly show that foliar fertilization can affect shoot growth in a positive way. Furthermore, the Fitofolis fertilizer obtained the best results compared to the control, which in some cases increased the growth up to $5 \mathrm{~cm}$. The mixture of the three fertilizers $(F+B+C)$ influenced shoot growth of gladioli in a positive way. In some varieties increases of $3 \mathrm{~cm}$ were shown compared to treatments with only Cropmax or Bionat Plus.

Like the shoot growth parameters, flower stem growth was influenced in a positive way by the foliar fertilization in all five varieties. Generally, the highest increases were observed in the plants fertilized with Bionat Plus, followed by Cropmax and Fitofolis. The mixture of foliar fertilizers in this case did not record as high an increase compared to the other three treatments. The macronutrients (N, P and K) are known to have effect on plant growth [23]. Nitrogen, phosphorus and potassium influenced the shoot growth and the flower stem length in a positive way. NPK used at an optimal dose can supplement sufficient nutrient uptake, which foster conditions for plants growth and development [24]. In some studies, it was also reported that B (boron) could increase-stimulate nutrient uptake, maintaining cell integrity and intensify respiration rate, which could promote growth and flower development [25-27].

Vase durability of Gladiolus is one of the most important considerations for consumers. Foliar fertilizer effects on vase durability have been reported on Rosa [28], Lilium [29], Anthurium andreanum [30] and Gladiolus [31,32]. In the present experiment, vase durability of the five gladioli varieties was improved compared to the control in almost all treatments. The longest vase durability was obtained under the Bionat Plus treatment, and the longest vase durability among the five varieties was observed for 'Green Star'. Gladiolus fading or wilting are important signalling factors of senescence [33]. Calcium (Ca) has an important role in regulating the senescence in gladioli cut flowers [34]. Ca increases membrane 
stability and reduces the level of reactive oxygen species, which could delay senescence in Gladiolus cut flowers [35]. However, in a study conducted by Dhakal et al. [31] it was concluded that phosphorus could also improve vase durability of gladioli cut flowers.

Daughter corm production is an important part of the gladioli propagation; our study results clearly indicate foliar fertilization has an important role in this sequence of the cultivation. Previous reports have also shown an increase in daughter corms production under foliar fertilization treatments [16,36-38]. Under our experimental conditions the highest increase was recorded in 'Frizzled Coral Lace' compared to the other four Gladiolus varieties. The mixture foliar fertilization $(\mathrm{F}+\mathrm{B}+\mathrm{C})$ improved the daughter corm production. This behaviour could be explained also with the variety characteristics, where previous results reported 'Frizzled Coral Lace' has a high yield of daughter corms. Daughter corm production could be influenced by nitrogen dose [39,40], and some studies have shown that daughter corm production is also influenced by applying a higher potassium dose $[15,16,41]$.

\section{Materials and Methods}

\subsection{Experimental Site and Plant Material}

Open field experiments were conducted between April and September 2018 at the Sapientia Hungarian University of Transylvania, Târgu Mureș (46 31'17" N 24³5'54" E). The gladioli corms were obtained from Sieberz Garden Centre (Gödölló, Hungary) and planted in five rows/block, each row containing 10 gladioli corms, with sizes of $12-14 \mathrm{~cm}$ in circumference. According to the soil analysis and of the analysis of its profile we can state that the type of soil at the experiment location is gley chernozem, carbonated in depth and clayish in the alluvial deposits (Epiaquic Hapludalfs) (Table 1).

Table 1. Planted soil proprieties.

\begin{tabular}{cccccccc}
\hline $\begin{array}{c}\text { Depth } \\
(\mathbf{c m})\end{array}$ & $\mathbf{p H}$ & $\begin{array}{c}\mathbf{P} \\
(\mathbf{p p m})\end{array}$ & $\begin{array}{c}\mathbf{K} \\
(\mathbf{p p m})\end{array}$ & $\begin{array}{c}\text { Humus } \\
\mathbf{\%}\end{array}$ & $\begin{array}{c}\mathbf{N} \\
\mathbf{\%}\end{array}$ & $\begin{array}{c}\text { Cohesion } \\
\text { Coefficient }\end{array}$ & $\begin{array}{c}\mathbf{C a C O}_{3} \\
\text { (ppm) }\end{array}$ \\
\hline $0-10$ & 7.55 & 586 & 1850 & 7.29 & 0.348 & 48 & 1.33 \\
$10-20$ & 7.48 & 520 & 1630 & 7.12 & 0.33 & 48.4 & 1.25 \\
$20-40$ & 7.44 & 487 & 1550 & 6.22 & 0.304 & 48.8 & \\
\hline
\end{tabular}

The average temperature during the experiment was $17.99^{\circ} \mathrm{C}$, the minimum was recorded in April $\left(15.4^{\circ} \mathrm{C}\right)$, and the maximum temperature in August $\left(21.83^{\circ} \mathrm{C}\right)$ (Figure 5). From Figure 5, it can be concluded that the average precipitation amount was $54.83 \mathrm{~mm}$ during the experimental months. The minimum precipitation was recorded in April at $15.40 \mathrm{~mm}$, and the maximum in June was $129.40 \mathrm{~mm}$. The precipitation and temperature data were collected using Delta-T devices WS-GP2 Automatic Weather Station (Delta-T Devices Ltd., Burwell, UK).

Morphological description of the five selected Gladiolus varieties:

- 'Black Beauty': flower colour dark burgundy; usually grows a flower stalk that is thin, straight, stiff; plant height 70-90 cm.

- 'Green Star': flower colour lime green; usually grows a flower stalk that is straight and vigorous; plant height $75-100 \mathrm{~cm}$.

- 'Nova Lux': flower colour bright yellow; the flower stalk is thin but strong; plant height $80-110 \mathrm{~cm}$.

- 'Zizane': flower colour combination of red and white; grows a straight, strong flower stalk; plant height $80-110 \mathrm{~cm}$.

- 'Frizzled Coral Lace': flower colour coral pink; tends to grow more flower stems; plant height $60-100 \mathrm{~cm}$.

Gladiolus corms were planted on 18 April 2018 with a row length of $25 \mathrm{~cm}$ and $15 \mathrm{~cm}$ between the plants. The plant growth was already observed at the end of the planting month. 


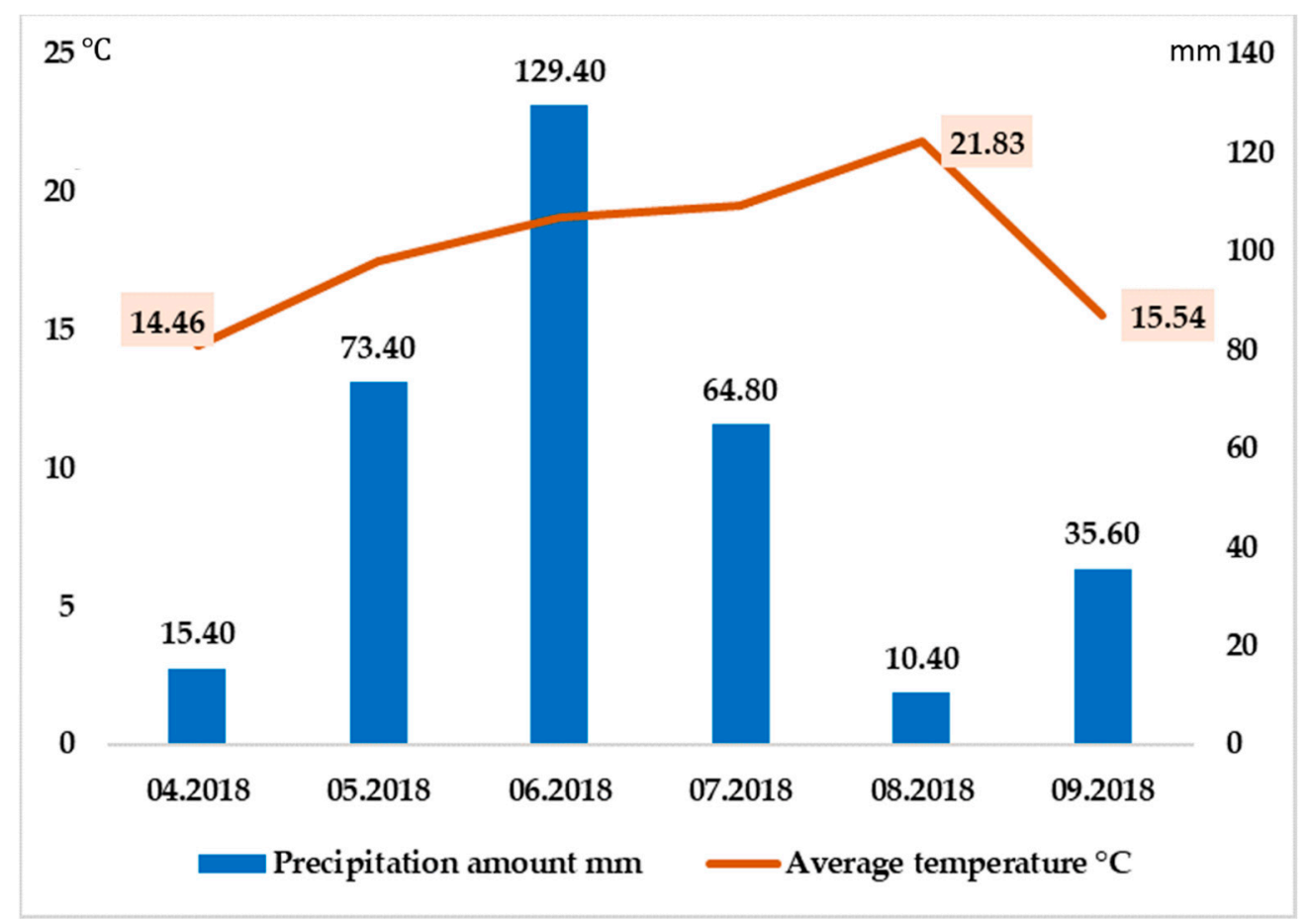

Figure 5. Meteorological conditions, precipitation and temperature during the field experiment (April-September 2018).

\subsection{Application of the Foliar Fertilization}

On 13 May, two weeks after sprouting, first shoot measurements and the first foliar fertilization were made, according to the experimental design: A-Control, B-Fitofolis (Chemtech, Târgu Mureș, Romania), C-Bionat Plus (Panetone, Timișoara, Romania), DCropmax (Blondy, Târgu Mureș, Romania) and E-the mixture of the three foliar fertilizers (first it was fertilized with Fitofolis, the second fertilization was made with Bionat Plus, the third with Cropmax, and the last one with the mixture of the three fertilizers in 1:1:1 proportion) (Table 2).

Table 2. Planting design: A: Control; B: Fitofolis; C: Bionat Plus; D: Cropmax; E: The mixture of Fitofolis, Bionat Plus and Cropmax $(F+B+C)$.

\begin{tabular}{ccccc}
\hline A & B & C & D & E \\
\hline Green Star & Black Beauty & Zizane & Frizzled Coral Lace & Nova Lux \\
Nova Lux & Green Star & Black Beauty & Zizane & Frizzled Coral Lace \\
Frizzled Coral Lace & Nova Lux & Green Star & Black Beauty & Zizane \\
Zizane & Frizzled Coral Lace & Nova Lux & Green Star & Black Beauty \\
Black Beauty & Zizane & Frizzled Coral Lace & Nova Lux & Green Star \\
\hline
\end{tabular}

The used foliar fertilizers content:

- Fitofolis: N-183 g/L; P-43 g/L; K-46 g/L; Fe-0.4 g/L;Cu-0.06 g/L; Mn-0.086 g/L; B-0.01 g/L; Zn-0.05 g/L; Mo-0.004 g/L.

- Bionat Plus: N-6.9\%; P-0.003\%; K-0.76\%; Mg-0.47\%; S-1.3\%; Ca- $0.05 \%$; B- $0.16 \%$; $\mathrm{Cu}-0.35 \%$; $\mathrm{Fe}-0.18 \% ; \mathrm{Mn}-0.06 \% ; \mathrm{Zn}-0.11 \%$.

- Cropmax: N-0.2\%; P-0.4\%; N-0.02\%; Fe-220 mg/L; Mg-550 mg/L; Zn-49 mg/L; Cu-35 mg/L; Mn-54 mg/L; B, Ca, Mo, Co, Ni-10 mg/L; auxin; cytokinin; gibberellin. 
The application of the foliar fertilizers was done with a hand sprayer; for each product a $2 \%$ solution was prepared. To prevent the fertilization from getting into the wrong row, we placed a plastic film between the rows to protect them from the other treatments.

On 2 June the second foliar fertilization was applied; the only difference was that the gladioli on bed $\mathrm{E}$ were sprayed with the Bionat Plus. The third fertilization was made on 20 June, for the last (E) gladioli bed, Cropmax foliar fertilizer was applied.

The last fertilization was done on 5 July; E bed was fertilized with the mixture of the three foliar fertilizations (Fitofolis, Bionat Plus, Cropmax) in 1:1:1 proportions. The first flower buds appeared on 13 July. We measured the flower stem length of each plant. The last shoots measurements were made before harvesting the five Gladiolus varieties (9 August).

\subsection{Vase Durability}

When almost all gladioli started flowering (11 August) we randomly harvested five flowered stems, at a cut distance of $5 \mathrm{~cm}$ above the soil, from each treatment/Gladiolus variety. The vase durability was studied for seven days, and the gladioli cut flowers were kept under the same conditions: at room temperature, in clean-fresh water, and monitored and noted every three hours.

The classification criteria for the vase durability were determined as follows:

- Ten points if the flower buds are healthy, the lower inflorescence is fully open, the colour is bright and typical for the variety, the stem is flexible and straight, the leaves are brightly coloured.

- Nine points if the second and third flower buds have opened, the petal edges on the first are starting to wilt slightly, the stem is losing a little of its hold.

- Eight points when the fourth and fifth flower buds have opened, the petals of the lowest flower start to wilt.

- Seven points if lowest flower fully open, withered, leaves completely lose their glossy colour, stem loses elasticity.

- Two points when the uppermost buds in the inflorescence is opened, and the ones underneath are constantly wilting.

The above was used to determine the maximum value of vase durability.

\subsection{Corms Propagation}

At the end of August, all inflorescences were harvested from the plants; however, we left two leaves on each Gladiolus plant, thus contributing to the growth of the corms. In this way most of the photoassimilation is destined for the growth of the daughter corms. By the end of September, when the plants had stopped nutrient uptake and the remaining leaves withered, we gathered corms of five Gladiolus varieties. We dried them and cleaned the remaining soil of the corms.

\subsection{Statistical Analysis}

All data were tested for normality of errors and homogeneity of variance. As all data were normally distributed, ANOVA followed by Tukey test were used to compare variances. The significance of the differences between the treatments was tested by applying two-way ANOVA, at a confidence level if $95 \%$. When the ANOVA null hypothesis was rejected, Tukey's Post hoc test was carried out to establish the statistically significant differences at $p<0.05$.

\section{Conclusions}

Gladioli growers strive to achieve the greatest possible stem length, vase durability and daughter corm production. The present study provides new experimental data on the responses of five Gladiolus varieties to foliar fertilization. For flower stem length and vase durability increase we recommend the use of Bionat Plus fertilizer, and for cut flowers the 'Green star' variety, which in our experiments had the best increases. The highest yield of 
daughter corm production was observed with the mixture of the three foliar fertilizations $(F+B+C)$. These approaches/results will help to enhance the production of Gladiolus, with a smaller footprint on the degradation and salinization of the cultivated lands. Due to the frequent changes in cultivated Gladiolus varieties, we propose repeating this experimental design in a few years to examine the effect of foliar fertilization on new and requested varieties on the market.

Author Contributions: Conceptualization, E.K.; methodology, E.K.; formal analysis, E.K. and Z.S.-V.; writing-original draft preparation, E.K. and Z.S.-V.; writing-review and editing, E.K. and Z.S.-V. All authors have read and agreed to the published version of the manuscript.

Funding: This research received no external funding.

Institutional Review Board Statement: Not applicable.

Informed Consent Statement: Not applicable.

Data Availability Statement: Not applicable.

Acknowledgments: The authors would like to express their special thanks to Cecilia Kurko, Kázmér Kovács and László Ferencz for the help with this research.

Conflicts of Interest: The authors declare no conflict of interest.

\section{References}

1. Machado, R.M.A.; Serralheiro, R.P. Soil salinity: Effect on vegetable crop growth. Management practices to prevent and mitigate soil salinization. Horticulturae 2017, 3, 30. [CrossRef]

2. Litalien, A.; Zeeb, B. Curing the earth: A review of anthropogenic soil salinization and plant-based strategies for sustainable mitigation. Sci. Total. Environ. 2020, 698, 134235. [CrossRef] [PubMed]

3. Tarchoune, I.; Sgherri, C.; Izzo, R.; Lachaâl, M.; Navari-Izzo, F.; Ouerghi, Z. Changes in the antioxidative systems of Ocimum basilicum L. (cv. Fine) under different sodium salts. Acta Physiol. Plant. 2012, 34, 1873-1881. [CrossRef]

4. Niu, J.; Liu, C.; Huang, M.; Liu, K.; Yan, D. Effects of Foliar Fertilization: A Review of Current Status and Future Perspectives. J. Soil Sci. Plant Nutr. 2021, 21, 104-118. [CrossRef]

5. Sathyanarayana, E.; Sudha, P.; Chawla, S.L. Impact of integrated nutrient management on growth and flowering of gladiolus (Gladiolus grandiflorus L.) cv. American beauty. Int. J. Chem. Stud. 2017, 5, 317-319.

6. Patil, B.; Chetan, H.T. Foliar fertilization of nutrients. Marumegh 2018, 3, 49-53.

7. Shahverdi, M.A.; Omidi, H.; Damalas, C.A. Foliar fertilization with micronutrients improves Stevia rebaudiana tolerance to salinity stress by improving root characteristics. Braz. J. Bot. 2020, 43, 55-65. [CrossRef]

8. Abdel-Kader, H.H.; El-Saady, W.A.; Zaky, H.A. Effect of Magnetized Water and NPK Fertilization Treatments on Growth and Field Performance of Gladiolus. J. Plant Prod. 2020, 11, 627-632. [CrossRef]

9. Şelaru, E. Cultivation of Garden Flowers (Cultura Florilor de Grădină); Ceres: Bucharest, Romania, 2007; pp. 88-92, 436-442.

10. Greving, A.J. Growing Gladiolus; University of Nebraska-Lincoln: Lincoln, Nebraska, 1987; Volume 978, pp. 1-5.

11. Tombolato, A.F.C.; Castro, J.L.; Matthes, L.A.F.; Leme, J.M. Melhoramento genético do gladíolo no IAC: Novos cultivares ‘IAC Carmim' e 'IAC Paranapanema'. Científica 2008, 33, 142-147.

12. Riaz, T.; Khan, S.N.; Javaid, A. Management of Fusarium corm rot of gladiolus (Gladiolus grandiflorus sect. Blandus cv. Aarti) by using leaves of allelopathic plants. Afr. J. Biotechnol. 2010, 9, 4681-4686.

13. Cantor, M.; Tolety, J. Gladiolus. In Wild Crop Relatives: Genomic and Breeding Resources; Springer: Berlin/Heidelberg, Germany, 2011; pp. 133-159.

14. Cantor, M.; Zaharia, D.; Pop, I. Results and new trends in breeding of romanian gladiolus. Acta Hortic. 2002, 624, 61-66. [CrossRef]

15. Saima, S.; Perveen, M.; Nawaz, M.; Ahmad, K.M.; Sultan, H. Comparison of Foliar Spray and Side Dressing of Potassium on Growth, Flowering, Productions of Corms in Gladiolus cv. Yellow Stone. Sarhad J. Agric. 2021, 37, 548-554. [CrossRef]

16. El-Naggar, A.A.M.; El-Nasharty, A.E. Effect of Potassium Fertilization on Growth, Flowering, Corms Production and Chemical Contents of Gladiolus hybrida, L. Cv. ASEJ 2016, 37, 714-728.

17. Bistgani, Z.E.; Siadat, S.A.; Bakhshandeh, A.; Pirbalouti, A.G.; Hashemi, M.; Maggi, F.; Morshedloo, M.R. Application of combined fertilizers improves biomass, essential oil yield, aroma profile, and antioxidant properties of Thymus daenensis Celak. Ind. Crop. Prod. 2018, 121, 434-440. [CrossRef]

18. Oliveira, K.S.; Prado, R.D.M.; Guedes, V.H.D.F. Leaf Spraying of Manganese with Silicon Addition Is Agronomically Viable for Corn and Sorghum Plants. J. Soil Sci. Plant Nutr. 2020, 20, 872-880. [CrossRef]

19. Bashir, M.; Khan, I.; Waseem Khan Qadri, R.; Tanveer, M.; Zain, M.; Ahmad, I. Growth and corm production of Gladiolus grandiflorus L. 'Essential' under different NPK regimes. J. Ornam. Plants 2016, 6, 11-19. 
20. El-Kot, H.R.; Abdallah, S.A.; Hassan, H.M.; Ali, M.A. effect of chemical nitrogen fertilizer level and humic acid rate on Gladiolus grandiflorus productivity. Sinai J. Appl. Sci. 2020, 9, 29-40. [CrossRef]

21. Onofrei, V.; Honermeier, B.; Lobiuc, A.; Burducea, M.; Teliban, G.C.; Jitareanu, C.D.; Cotunoaea, R.C.; Robu, T. Effects of foliar ecological fertilization on inflorescence yield and chlorophyll parameters of Calendula officinalis L. An. Stiintifice Univ. Al. I. Cuza Iasi 2016, 62, 142.

22. Onofrei, V.; Teliban, G.-C.; Burducea, M.; Lobiuc, A.; Sandu, C.B.; Tocai, M.; Robu, T. Organic foliar fertilization increases polyphenol content of Calendula officinalis L. Ind. Crop. Prod. 2017, 109, 509-513. [CrossRef]

23. Onofrei, V.; Benchennouf, A.; Jancheva, M.; Loupassaki, S.; Ouaret, W.; Burducea, M.; Lobiuc, A.; Teliban, G.C.; Robu, T. Ecological foliar fertilization effects on essential oil composition of sweet basil (Ocimum basilicum L.) cultivated in a field system. Sci. Hortic. 2018, 239, 104-113. [CrossRef]

24. Gaber, K.M. Vegetative and flowering growth of geranium as affected by mineral fertilization and ascorbic acid foliar application. Middle East J. Appl. Sci. 2019, 9, 220-230.

25. Ali, S.; Javed, H.U.; Rehman, R.N.U.; Sabir, I.A.; Naeem, M.S.; Siddiqui, M.Z.; Saeed, D.A.; Nawaz, M.A. Foliar application of some macro and micro nutrients improves tomato growth, flowering and yield. Int. J. Biosci. 2013, 3, 280-287. [CrossRef]

26. Singh, A.; Sharma, B.P.; Dilta, B.S.; Laishram, N.; Gupta, Y.C.; Bhardwaj, S.K. Effects of fertilization on quality flower production and foliar nutrient content of carnation (Dianthus caryophyllus L.) cv. master. Bangladesh J. Bot. 2015, 44, 133-137. [CrossRef]

27. Mudassir, S.; Ahmad, R.; Anjum, M.A. Foliar Application of Micronutrients Enhances Growth, Flowering, Minerals Absorption and Postharvest Life of Tuberose (Polianthes tuberosa L.) in Calcareous Soil. J. Hortic. Sci. Technol. 2021, 4, 41-47. [CrossRef]

28. Bilal, H.H.; Tahir, R.; Adnan, M.; Ali, S.M.; Islam, H.; Umer, M.S.; Mir, F.A.; Ahmad, R.I.; Iftikhar, M. Does foliar application of macro and micronutrients have any impact on roses production? A review. Ann. Rev. Res. 2020, 1, 555677. [CrossRef]

29. Darandeh, N.; Hadavi, E. Effect of Pre-Harvest Foliar Application of Citric Acid and Malic Acid on Chlorophyll Content and Post-Harvest Vase Life of Lilium cv. Brunello. Front. Plant Sci. 2012, 2, 106. [CrossRef] [PubMed]

30. Waheeduzzama, M.; Jawaharlal, M.; Arulmozhiyan, R.; Indhumathi, K. Effect of integrated nutrient management practices on flower quality and vase life of Anthurium andreanum cv. Meringue. J. Ornam. Hortic. 2006, 9, 142-144.

31. Dhakal, K.; Khanal, D.; Ayer, D.K.; Khanal, A.P.; Pandey, L.; Pant, S.S.; Upadhyay, K.; Magar, S.S.B.; Pandey, L.; Prasad, M.L.; et al. Effect of nitrogen and phosphorous on growth, development and vase life of gladiolus. RRJoAST 2017, 6, 1-7.

32. Allawii, S.S.; Al-Atrakchii, A.O. effect of foliar application of calcium chloride and salicylic acid on growth and flowering of three Gladiolus $\times$ hortulanus L. cultivars. Mesop. J. Agric. 2020, 48, 45-58. [CrossRef]

33. Chore, K.J.; Mwangi, M.; Karori, S.M.; Kibe, A.M. Changes in carbohydrates associated with senescence of cut gladiolus spikes under pulsing and wet cold storage durations. Afr. Crop Sci. J. 2020, 28, 41-53. [CrossRef]

34. Sairam, R.K.; Vasanthan, B.; Arora, A. Calcium regulates Gladiolus flower senescence by influencing antioxidative enzymes activity. Acta Physiol. Plant. 2011, 33, 1897-1904. [CrossRef]

35. Ahmad, M.; Rab, A. Calcium effects on post-harvest attributes and vase life of gladiolus using different methods of application. Pak. J. Bot. 2020, 52, 167-179. [CrossRef]

36. Sathyanarayana, E.; Patil, S.; Bahubali, M.; Chawla, S.L. Effect of INM on gladiolus (Gladiolus grandiflorus, L.) cv. American Beauty under Navsari and Tansa Conditions. Int. J. Pure App. Biosci. 2018, 6, 48-55. [CrossRef]

37. Ghanbari, J.; Khajoei-Nejad, G.; Van Ruth, S.M.; Aghighi, S. The possibility for improvement of flowering, corm properties, bioactive compounds, and antioxidant activity in saffron (Crocus sativus L.) by different nutritional regimes. Ind. Crop. Prod. 2019, 135, 301-310. [CrossRef]

38. Shyla, R.; Ruby, M.; Rameshkumar, S. Effect of gypsum and micronutrients on spike and corm yield of gladiolus (Gladiolus grandiflorus) cv. Guvari. Crop Res. 2021, 56, 0970-4884.

39. Kumar, E.; Misra, R.L. Response of gladiolus to nitrogen, phosphorus and potassium fertilization. J. Ornam. Hortic. 2003, 6, 95-99.

40. Patel, N.M.; Desai, J.R.; Saravaiya, S.N.; Patel, N.B.; Patel, K.A.; Patel, R.B. Influence of chemical fertilizers on growth, quality, corm and cormel production of gladiolus (Gladiolus grandiflorus L.) cv. SANCERREE under South Gujarat conditions. TAJH 2010, $5,123-126$.

41. Lehri, S.M.; Kurd, A.A.; Rind, M.A.; Bangulzai, N.A. The response of Gladiolus tristis L. to N and $\mathrm{P}_{2} \mathrm{O}_{5}$ fertilizers. SJA 2011, 27, 185-188. 